\title{
What Makes the Gears Go 'Round? Factors Influencing Bicycling to Suburban Regional Rail Stations
}

\author{
Matthew Graystone*, Raktim Mitra ${ }^{\dagger}$ \\ Keywords: bicycling, transit access trips, first/last mile, suburban, built environment, commuter rail \\ https://doi.org/10.32866/001c.12557
}

Transport Findings

\begin{abstract}
In North America, most suburban commuters who use rail transit drive and park at stations, offsetting some benefits of commuter rail. Using passenger survey data collected at three rail stations near Toronto, Canada, we explored the correlates of bicycling for station access trips in a suburban context. Other than automobile ownership, no socio-demographic characteristics were associated with the likelihood of bicycling. Frequency of bicycling for transportation and recreation, preference toward sustainable, and active transportation, and weather-related comfort were correlated with bicycling to a station. Street density along shortest travel route and having to cross a major highway were barriers to bicycling.
\end{abstract}

\section{RESEARCH QUESTIONS AND HYPOTHESIS}

Research on bicycling to transit, particularly in a North American suburban context, is limited (Bachand-Marleau, Larsen, and El-Geneidy 2011; Mitra and Schofield 2019). A recent systematic literature review (Pinder et al. 2018) identified 28 existing studies that have focused on transit-cycle integration; 11 of these have a North American focus, and none of these 11 studies includes a disaggregate analysis of cycling mode choice behavior. For example, Ravensbergen et al. (2018) analyzed data collected by Metrolinx, the public operator of the regional commuter transit system- GO Transit- in Southern Ontario, Canada, and explored stated barriers to cycling to train stations and bus stops across the region. The paper did not specifically focus on the suburban context nor examine mode choice behaviour, likely due to the unavailability of geographical data.

In this paper, we explore the potential for bicycling to commuter rail stations, to inform station access planning and policy that would reduce demand for car parking. More specifically, we examine the socio-demographic, attitudinal, and environmental correlates of the likelihood of bicycling for transit access trips. Our key hypothesis is that a passenger's travel-related attitudes and the built environment conditions of the travel route will affect their probability of cycling.

\footnotetext{
* School of Urban and Regional Planning, Ryerson University

† School of Urban and Regional Planning, Ryerson University Link: https://www.ryerson.ca/surp/people/faculty/raktimmitra/
} 


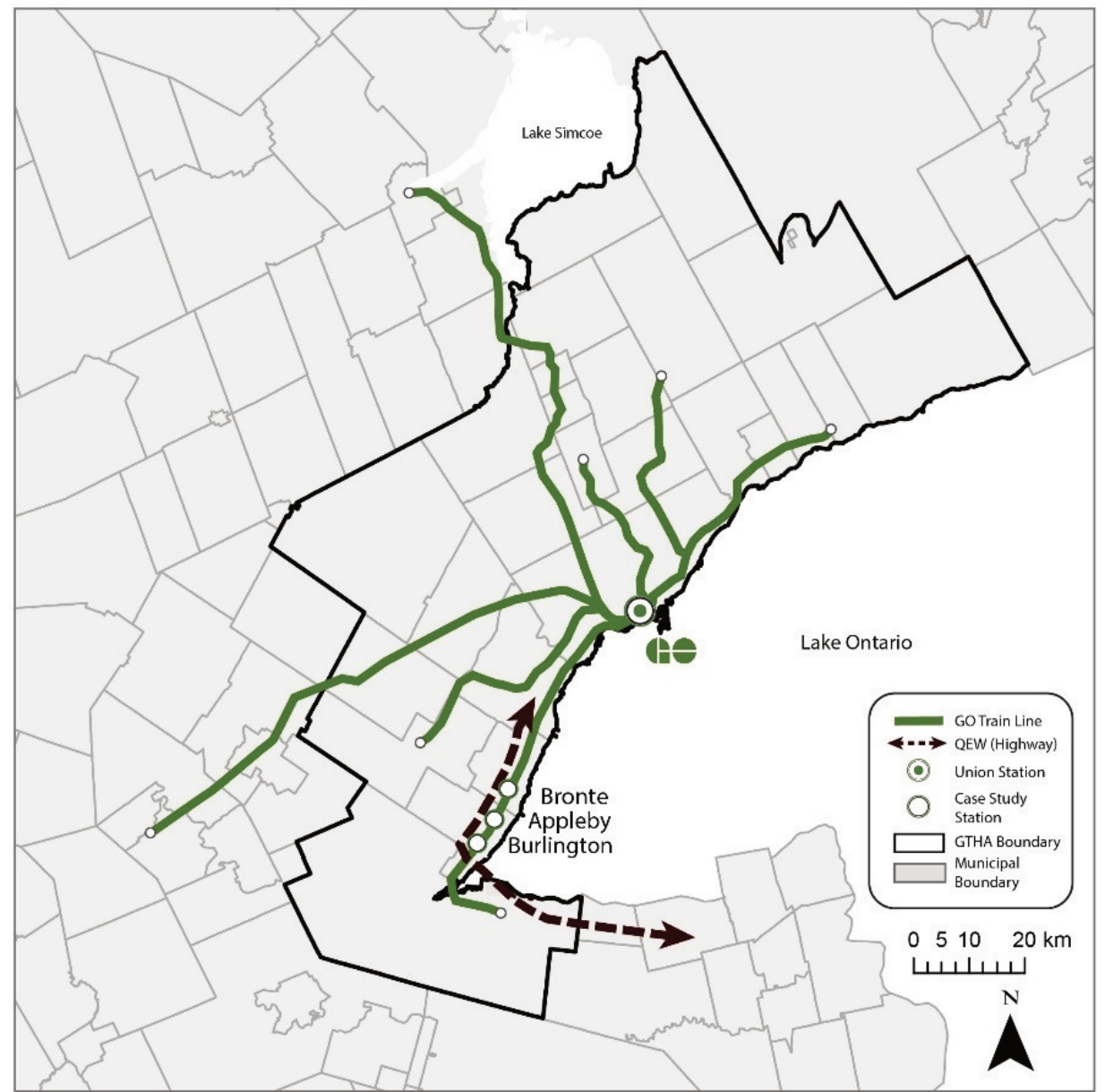

Figure 1. Study area, also showing GO Train routes

\section{METHODS AND DATA}

\section{PASSENGER SURVEY OF BICYCLING BEHAVIOR}

GO Transit has an extensive network of bus and train services across Sourthern Ontario. Trains operate along seven corridors centering on Union Station in downtown Toronto, the largest employment center in Canada (Fig. 1).

We conducted an online survey of GO Train passengers in fall 2017 at three suburban stations. The selected stations - Burlington, Appleby, and Bronte - are located on the Lakeshore West train corridor, which is GO Transit's highest ridership corridor. The surveys were collected on six weekdays (two days at each station) under sunny and moderate weather conditions. A research assistant distributed postcards with a link to the survey during morning peak ( $7 \mathrm{am}$ to $8 \mathrm{am}$ ) to as many passengers as possible, who were asked to complete the survey during the journey or within 24 hours after travel. In the survey, we asked the respondents about their transportation mode choice motivations and preferences, bicycling comfort in different hypothetical environmental conditions, as well as preference for end-of-trip facilities (e.g., parking, change 
Table 1. Descriptive statistics $(n=265)$

\begin{tabular}{|c|c|c|c|c|}
\hline Variable & $n$ & Description & Mean (S.D.) & $\%$ \\
\hline \multicolumn{5}{|l|}{ Socio-demographic characteristics } \\
\hline Age & 265 & Age of the passenger. & $39.5(10.2)$ & \\
\hline Gender & 265 & 1 if the passenger was a male; 0 otherwise. & & 56.2 \\
\hline Employed fulltime & 263 & 1 if passenger is a full-time employee; 0 otherwise. & & 93.5 \\
\hline Student & 263 & 1 if the passenger was a student; 0 otherwise. & & 4.9 \\
\hline Household Income & 241 & Passenger's household income per year (CAD) & & \\
\hline $0-25 k$ & & & & 1.6 \\
\hline $25-50 k$ & & & & 3.6 \\
\hline $50-75 k$ & & & & 9.9 \\
\hline $75-100 k$ & & & & 11.1 \\
\hline $100-150 k$ & & & & 25.8 \\
\hline $150 \mathrm{k}$ or more & & & & 48.0 \\
\hline Multiple vehicle household & 265 & $\begin{array}{l}1 \text { if the passenger was from household with access to } \\
\text { multiple vehicles ( } 2 \text { or more); } 0 \text { otherwise. }\end{array}$ & & 72.5 \\
\hline Frequent cyclist & 230 & $\begin{array}{l}1 \text { if the passenger cycled at least once a month or } \\
\text { more for transportation AND recreation purposes; } \\
0 \text { if the passenger cycled less frequently for either } \\
\text { transportation or recreation or both. }\end{array}$ & & 10.0 \\
\hline Distance $(\mathrm{km})$ & 213 & Shortest distance from home to station & & \\
\hline $0-2 \mathrm{~km}$ & & & & 13.1 \\
\hline $2-5 \mathrm{~km}$ & & & & 26.2 \\
\hline $5+k m$ & & & & 60.7 \\
\hline Travel mode for station access & 265 & & & \\
\hline Walked & & & & 3.0 \\
\hline Cycled & & & & 5.7 \\
\hline Drove and parked & & & & 72.5 \\
\hline Took transit & & & & 2.3 \\
\hline Dropped off or carpooled & & & & 16.6 \\
\hline
\end{tabular}

room, storage lockers). These perceptions and motivations were captured on a 5-point scale based on the respondent's agreement to a group of statements. The full survey instrument can be found elsewhere (Mitra and Schofield 2019).

Approximately 1,550 postcards were distributed, and we received 306 responses, at a $19.7 \%$ response rate. Of these respondents, 265 provided data on their travel mode to a GO Train station, age, and gender. The sample characteristics are summarized in Table 1, along with the number of responses to each question.

\section{BUILT ENVIRONMENT DATA}

We determined passengers' home locations based on their six-digit postal codes $(n=213)$, which represent whole or part of a residential block. Several built environment variables were computed using GIS. We conducted this analysis at the Dissemination Area (DA) level, which is the smallest geographical unit for which census data is available. The data used to compute these variables came from DMTI Spatial's land use dataset 2015 (LUR), Statistics Canada 2011 Census, and Environics Analytics Demographic Estimates. We estimated 
the shortest travel route between a passenger's home and station using ArcGIS network analysis. The built environment features within all DAs located within a $500 \mathrm{~m}$ buffer of the shortest route were summarized and normalized. Through visual inspection of the home and station locations on a Google map, we identified whether the passenger had to cross the QEW (a major controlled access highway).

\section{DATA ANALYSIS}

We explored a total of 17 variables relating to travel motivations, perceptions, and comfort bicycling in different weather and environmental conditions. To reduce the dimensionality of the data and identify clearly distinguishable 'factors', we conducted a principal component analysis (PCA). The PCA produced six components that cumulatively explained $72 \%$ of the total variance (Table 2).

We adopted a binomial logistic regression approach to explore the correlates of the likelihood of bicycling (versus other modes). However, our dataset is relatively small $(\mathrm{n}=265)$, with few instances of the desired outcome (i.e., bicycling to GO station), which could potentially lead to a 'separation' problem in model estimation. To overcome this potential problem, Firth logistic regression models with penalized likelihood method were estimated (Firth 1993; Heinze and Puhr 2010). Also, we estimated partially adjusted models that explored the correlation between one variable of interest and the log-likelihood of bicycling, controlling for variations in age and gender, neither of which were associated with the propensity of bicycling at $\alpha=0.05$.

\section{FINDINGS}

Of the socio-demographic variables tested, respondents from multi-vehicle households were less likely to bicycle to a GO Train station (Table 3). We also found a strong positive correlation between past-month's bicycling frequently for transportation and recreational purposes and the likelihood of bicycling to a station, unsurprisingly indicating that those who use a bicycle more for various other activities would also be more likely to use bicycles for station access trips. A passenger's household income was not associated with cycling to suburban stations, contrary to findings from research that has focused broadly on all transit access trips (Chakour and Eluru 2014; Chan and Farber 2019; Flamm and Rivasplata 2014; Ravensbergen et al. 2018). 
Table 2. Factor loadings from Principal Component Analysis

\begin{tabular}{|c|c|c|c|c|c|c|}
\hline \multirow[t]{2}{*}{ Variables } & \multicolumn{6}{|c|}{ Factor names } \\
\hline & $\begin{array}{l}\text { Efficiency } \\
\text { Motivation }\end{array}$ & $\begin{array}{l}\text { Ecological } \\
\text { motivation }\end{array}$ & $\begin{array}{l}\text { End-of-trip } \\
\text { facilities }\end{array}$ & Weather & $\begin{array}{l}\text { High-traffic } \\
\text { comfort }\end{array}$ & $\begin{array}{c}\text { Low-traffic } \\
\text { comfort }\end{array}$ \\
\hline \multicolumn{7}{|l|}{ It's important for me to... } \\
\hline Get to the $\mathrm{GO}$ station as quickly as possible & .764 & & & & & \\
\hline Have flexibility in the time I leave for the $G O$ station & .822 & & & & & \\
\hline Choose environmentally sustainable ways to get around & & .790 & & & & \\
\hline Be physically active & & .790 & & & & \\
\hline \multicolumn{7}{|l|}{$\begin{array}{l}\text { How important is it to have the following facilities at the GO } \\
\text { station? }\end{array}$} \\
\hline A secure bike parking room & & & .744 & & & \\
\hline Change rooms and showers & & & .846 & & & \\
\hline Lockers for temporary storage & & & .854 & & & \\
\hline Bike repair tools and a pump & & & .840 & & & \\
\hline \multicolumn{7}{|l|}{ I won't cycle when... } \\
\hline It's raining* & & & & .891 & & \\
\hline It's too cold* & & & & .867 & & \\
\hline There is ice or snow on the ground ${ }^{*}$ & & & & .833 & & \\
\hline It's too hot or humid* & & & & .682 & & \\
\hline \multicolumn{7}{|l|}{ Would you feel comfortable cycling in... } \\
\hline A two-lane road with moderate traffic and a painted bike lane & & & & & .869 & \\
\hline A busy arterial road with a painted bike lane & & & & & .865 & \\
\hline A busy arterial road with a bike path beside the road & & & & & .693 & \\
\hline A quiet residential street with no cycling facilities & & & & & & .857 \\
\hline A multi-use path, separate from the street & & & & & & .853 \\
\hline
\end{tabular}

Note: ${ }^{*}$ Reverse coded variable.

PCA was conducted using a varimax orthogonal rotation method.

Kaiser-Meyer-Olkin (KMO) measure of sampling adequacy: 0.76; Bartlett's test of sphericity was statistically significant $(\mathrm{p}<0.001)$ 
Table 3. Results from Firth adjusted logistic regression models.

\begin{tabular}{|c|c|c|c|c|c|}
\hline \multirow[b]{2}{*}{ Variable } & \multicolumn{5}{|c|}{$\begin{array}{l}\text { Cycled to GO Train station on the day of survey (versus did not cycle } \\
\text { to GO station) }\end{array}$} \\
\hline & $n$ & $\begin{array}{l}\text { Coef. } \\
\text { (S.E.) }\end{array}$ & $\begin{array}{l}\text { Odds Ratio } \\
(95 \% \mathrm{Cl})\end{array}$ & $\begin{array}{l}\text { Chi- } \\
\text { square }\end{array}$ & $\mathrm{p}$ value \\
\hline \multicolumn{6}{|l|}{ Socio-demographic characteristics } \\
\hline Employed fulltime & 263 & $\begin{array}{l}-0.20 \\
(0.96)\end{array}$ & $\begin{array}{l}0.82(0.16- \\
\quad 8.53)\end{array}$ & 0.04 & 0.840 \\
\hline Student & 263 & $\begin{array}{l}0.58 \\
(0.99)\end{array}$ & $\begin{array}{l}1.78(0.17- \\
9.81)\end{array}$ & 0.31 & 0.575 \\
\hline Household Income & 241 & $\begin{array}{c}0.21 \\
(0.26)\end{array}$ & $\begin{array}{l}1.23(0.76- \\
2.25)\end{array}$ & 0.63 & 0.426 \\
\hline Multiple vehicle household ( 2 or more) & 265 & $\begin{array}{l}-1.98 \\
(0.57)\end{array}$ & $\begin{array}{l}0.14(0.04- \\
\quad 0.41)\end{array}$ & 13.20 & $<0.001$ \\
\hline Frequent cyclist & 230 & $\begin{array}{c}2.87 \\
(0.61))\end{array}$ & $\begin{array}{c}17.64 \\
(5.52-61.0)\end{array}$ & 21.98 & $<0.001$ \\
\hline \multicolumn{6}{|l|}{ Travel motivation, perception, and cycling comfort factor scores } \\
\hline Efficiency motivation & 261 & $\begin{array}{l}-0.12 \\
(0.26)\end{array}$ & $\begin{array}{l}0.88(0.53- \\
1.51)\end{array}$ & 0.22 & 0.641 \\
\hline Ecological motivation & 261 & $\begin{array}{c}1.04 \\
(0.30)\end{array}$ & $\begin{array}{l}2.83(1.60- \\
5.39)\end{array}$ & 13.85 & $<0.001$ \\
\hline End-of-trip Facilities & 261 & $\begin{array}{l}-0.00 \\
(0.25)\end{array}$ & $\begin{array}{l}1.00(0.61- \\
1.70)\end{array}$ & 0.00 & 0.990 \\
\hline Weather* & 261 & $\begin{array}{c}0.94 \\
(0.22)\end{array}$ & $\begin{array}{l}2.57(1.72- \\
\quad 4.03)\end{array}$ & 20.56 & $<0.001$ \\
\hline High-traffic comfort & 261 & $\begin{array}{c}0.17 \\
(0.28)\end{array}$ & $\begin{array}{l}1.19(0.69- \\
2.20)\end{array}$ & 0.37 & 0.544 \\
\hline Low-traffic comfort & 261 & $\begin{array}{l}-0.33 \\
(0.22)\end{array}$ & $\begin{array}{l}0.72(0.48- \\
1.16)\end{array}$ & 1.95 & 0.163 \\
\hline \multicolumn{6}{|l|}{ Built environment } \\
\hline Distance (0-2 km) & 213 & $\begin{array}{l}1.55 \\
(0.79)\end{array}$ & $\begin{array}{l}4.71(1.08- \\
23.93)\end{array}$ & 3.50 & 0.061 \\
\hline Distance $(2-5 \mathrm{~km})$ & 213 & $\begin{array}{l}1.09 \\
(0.71)\end{array}$ & $\begin{array}{l}2.98(0.70- \\
13.60)\end{array}$ & 2.22 & 0.136 \\
\hline Crossed QEW (major highway) & 213 & $\begin{array}{l}-2.85 \\
(0.85)\end{array}$ & $\begin{array}{l}0.06(0.01- \\
0.25)\end{array}$ & 17.82 & $<0.001$ \\
\hline $\begin{array}{l}\text { Dedicated cycling facility- cycle track and painted bicycle } \\
\text { lane (DA, } \mathrm{km} / \mathrm{km}^{2} \text { ) }\end{array}$ & 213 & $\begin{array}{c}0.10 \\
(0.22)\end{array}$ & $\begin{array}{l}1.11(0.68- \\
1.71)\end{array}$ & 0.19 & 0.661 \\
\hline Percent of residential land use & 213 & $\begin{array}{l}-0.95 \\
(1.60)\end{array}$ & $\begin{array}{l}0.39(0.02- \\
16.35)\end{array}$ & 0.31 & 0.575 \\
\hline Population density (DA, pop/ $/ \mathrm{km}^{2}$ ) & 213 & $\begin{array}{c}8.5 \\
(0.00)\end{array}$ & $\begin{array}{l}1.00(1.00- \\
1.00)\end{array}$ & 0.24 & 0.624 \\
\hline Street Density (DA, km/km²) & 213 & $\begin{array}{l}-0.39 \\
(0.18)\end{array}$ & $\begin{array}{l}0.68(0.47- \\
0.96)\end{array}$ & 4.83 & 0.028 \\
\hline \multicolumn{6}{|l|}{ Note: } \\
\hline \multicolumn{6}{|l|}{ *Reverse-coded variable. } \\
\hline \multicolumn{6}{|c|}{ Firth Adjusted Binomial logistic regressions. All models were adjusted for variations in a passenger's age and gender. } \\
\hline \multicolumn{6}{|c|}{ Coefficients in bold face are statistically significant at $\alpha=0.05$; coefficients in bold-italics are significant at $\alpha=0.10$. } \\
\hline
\end{tabular}

Next, and in regard to passenger attitudes and preferences, we found that ecological motivation (i.e., preference toward environmentally sustainable transportation choices and physical activity) was positively associated with the odds of bicycling to the station $(\mathrm{OR}=2.83)$. In addition, comfort bicycling in adverse weather and climatic conditions was positively associated with 
bicycling $(\mathrm{OR}=2.57)$. In contrast, preference toward facilities at a GO Station (e.g., secure parking room, change room, shower) did not explain bicycling for station access.

Several built environment characteristics along the shortest route may explain bicycling for transit access trips. Specifically, distance between home and station locations was moderately associated with the probability of cycling; those living less than $2 \mathrm{~km}$ from station were 4.6 times more likely to use a bicycle ( $\alpha=0.1$ ) when compared to respondents living more than $5 \mathrm{~km}$ away. Having to cross the QEW (a major highway) to get to a station reduced the likelihood of cycling. In other words, those residing on the other side of the QEW from their respective access station would be 0.06 times or $94 \%$ less likely to bicycle. Additionally, density of streets was negatively correlated with bicycling for transit access trips, perhaps because in a suburban context higher street density can represent a built environment with higher traffic volume.

Contrary to the popular assumption (Cervero, Caldwell, and Cuellar 2013), the presence of bicycling facilities (which were mostly painted bicycle lanes on major suburban roads) did not change the probability of cycling. In addition, the self-reported comfort level in different road conditions had no impact on bicycling. While empirical research has produced mixed evidence of the impact of bicycle infrastructure (Buehler and Dill 2016), suburban contexts are understudied and a more nuanced examination of the relationship between suburban bicycle infrastructure and mode choice remains a topic for future research.

Many of our findings contradict what is expected in urban settings and emphasize the importance of bicycling research focusing on the North American suburban context. The empirical findings can be used by municipalities and commuter rail operators alike in developing or improving policies, plans and programs that would reduce automobile dependence and car parking demand at stations. For example, 62\% of current GO Train passengers drive to a station, and as Metrolinx plans for major service expansion that might produce up to an additional 150,000 passengers per day, a continuation of current station access behaviour will create significant pressure on existing parking facilities (Metrolinx 2016). As a result, promoting alternative means for station access trips, such as bicycling, has become a more important policy issue than ever, and the results from this study begin to identify customers who could be targeted for marketing campaigns as well as to emphasize the importance of safer bicycling environments.

\section{ACKNOWLEDGMENTS}

This research was supported by a Social Sciences and Humanities Research Council of Canada (SSHRC) Insight Grant. James Schofield at Ryerson University conducted the surveys. 
This is an open-access article distributed under the terms of the Creative Commons Attribution 4.0 International License (CCBY-NC-4.0). View this license's legal deed at https://creativecommons.org/ licenses/by-nc/4.0 and legal code at https://creativecommons.org/licenses/by-nc/4.0/legalcode for more information. 


\section{REFERENCES}

Bachand-Marleau, Julie, Jacob Larsen, and Ahmed M. El-Geneidy. 2011. "Much-Anticipated Marriage of Cycling and Transit." Transportation Research Record: Journal of the Transportation Research Board 2247 (1): 109-17. https://doi.org/10.3141/2247-13.

Buehler, Ralph, and Jennifer Dill. 2016. "Bikeway Networks: A Review of Effects on Cycling.” Transport Reviews 36 (1): 9-27. https://doi.org/10.1080/01441647.2015.1069908.

Cervero, Robert, Benjamin Caldwell, and Jesus Cuellar. 2013. "Bike-and-Ride: Build It and They Will Come.” Journal of Public Transportation 16 (4): 83-105. https://doi.org/10.5038/ 2375-0901.16.4.5.

Chakour, Vincent, and Naveen Eluru. 2014. "Analyzing Commuter Train User Behavior: A Decision Framework for Access Mode and Station Choice." Transportation 41 (1): 211-28. https://doi.org/10.1007/s11116-013-9509-y.

Chan, Kevin, and Steven Farber. 2019. "Factors Underlying the Connections between Active Transportation and Public Transit at Commuter Rail in the Greater Toronto and Hamilton Area." Transportation, May. https://doi.org/10.1007/s11116-019-10006-w.

Firth, DAVID. 1993. "Bias Reduction of Maximum Likelihood Estimates.” Biometrika 80 (1): 27-38. https://doi.org/10.1093/biomet/80.1.27.

Flamm, B., and C. Rivasplata. 2014. "Perceptions of Bicycle-Friendly Policy Impacts on Accessibility to Transit Services: The First and Last Mile Bridge.” MTI Report, 12-10. https://transweb.sjsu.edu/sites/default/files/1104-bicycle-policy-transit-accessibility-first-lastmile.pdf.

Heinze, Georg, and Rainer Puhr. 2010. "Bias-Reduced and Separation-Proof Conditional Logistic Regression with Small or Sparse Data Sets.” Statistics in Medicine 29 (7-8): 770-77. https://doi.org/10.1002/sim.3794.

Metrolinx. 2016. "GO Rail Station Access Plan. Government of Ontario.” http://www.metrolinx.com/en/regionalplanning/projectevaluation/studies/ GO_Rail_Station_Access_Plan_EN.pdf.

Mitra, Raktim, and James Schofield. 2019. "Biking the First Mile: Exploring a Cyclist Typology and Potential for Cycling to Transit Stations by Suburban Commuters." Transportation Research Record: Journal of the Transportation Research Board 2673 (4): 951-62. https://doi.org/10.1177/ $\underline{0361198119837229 .}$.

Pinder, M., L. Ravensbergen, G. Liu, R. Buliung, and M.J. Roorda. 2018. "What Factors Affect Bike-and-Ride? A Review of the Recent Literature. Presented at the 97th Annual Meeting of the Transportation Research Board, Washington, DC, 2018.”

Ravensbergen, Léa, Ron Buliung, Meaghan Mendonca, and Naren Garg. 2018. "Biking to Ride: Investigating the Challenges and Barriers of Integrating Cycling with Regional Rail Transit.” Transportation Research Record: Journal of the Transportation Research Board 2672 (8): 374-83. https://doi.org/10.1177/0361198118777080. 